\title{
Impact of Blast Design Parameters on Blasted Muckpile Profile in Building Stone Quarries
}

\author{
Abhishek Sharma*, Arvind Kumar Mishra, Bhanwar Singh Choudhary \\ Department of Mining Engineering, Indian Institute of Technology (Indian School of Mines), Dhanbad 826004, India
}

Corresponding Author Email: abhishekmbm@rediffmail.com

https://doi.org/10.18280/acsm.430105

Received: 28 October 2018

Accepted: 12 January 2019

\section{Keywords:}

stone quarries, drill-blast design parameters, muck profile, throw, drop, lateral spread

\begin{abstract}
The purpose of this research is to investigate the influence of blast design parameters and key blasted muck-pile properties. Apart from steel and cement, crushed stone aggregates is indispensable construction material produced by crushing of raw stone boulders raised from stone quarries through the conventional process of drilling and blasting. Controllable blast design parameters i.e. bench height, spacing, burden, stemming, bench stiffness ratio and powder factor have been found to influence the blasted muckpile properties to a greater extent. It has been studied and reported that the properties of blasted muckpile influence the performance of the loading equipment as well as balance sheet of the mining operations. In this paper, an attempt has been made to investigate the influence of blast design parameters and key blasted muckpile properties i.e. throw, drop, and lateral spread. Extensive field trials and analysis of results revealed that throw, drop and lateral spread of the blasted muckpile exhibited strong dependence on blast design parameters. Optimum muckpile profile, as observed in the field and also, recommended by the excavators' original equipment manufacturer, in order to achieve the optimum operating performance of excavators, were recorded at burden value of 20-21 times the hole diameter, spacing to burden ratio in range of 1.30 to 1.40 , stemming to burden ratio between 0.9 to 1.05 , bench stiffness ratio in range of 4.0 to 4.25 and powder factor range of 0.95 to $1.05 \mathrm{~kg} / \mathrm{cum}$. The above conclusions shall be useful for practicing mining engineers for stone quarries in similar rock mass condition in designing the blast to obtain the optimum muck pile profile for efficient operation of excavators.
\end{abstract}

\section{INTRODUCTION}

A country's level of human and economic development is closely related to its levels of achievement in physical and social infrastructure. The role of infrastructure is very critical in a developing country like India as infrastructure is strongly related to economic growth and poverty reduction [1]. For India to maintain the growth momentum, it is essential to strengthen infrastructure facilities such as transportation, energy, communication, and so on [2]. A country's physical infrastructure covers roads and highways, airports, railways, bridges, dams, power plants, metro rail and mono rail systems, urban mass rapid transit systems, defence bases, institutional, commercial and residential buildings and factories. Development of physical infrastructure in India not only contributes approximately $10 \%$ to its gross domestic product but also accounts for more than $65 \%$ of the country's total capital formation [3]. Apart from steel and cement, manufactured stone aggregates including crushed sand is an essential raw material for any construction mix. Driven by emphasis on development of physical infrastructure in India, which in turn, fuelled the demand of manufactured aggregates, country's annual consumption of stone aggregates is expected to reach a colossal level of 2.5 billion metric tons by 2020 [4].

Stone aggregates are manufactured by crushing of raw stone boulders which are produced in stone quarries. The construction standards followed in India or elsewhere require the stone deposits and crushes aggregates qualify the criterion as regards uniaxial compressive strength, loose and bulk density, specific gravity, percentage of water absorption, aggregates crushing value, aggregates impact value, Los Angles abrasion value and stripping value. Due to stringent requirement on quality, durability and strength aspects, most of the stone deposits which serve as source of the construction aggregates possess hard rocks like granite, gneiss, basalt, gabbro, sandstone, quartzite to name a few $[5,6]$.

Due to tough physical and mechanical properties of these rock masses, drilling and blasting, by far, remains the most economical and productive method of disintegration of rock from its mother strata. The conventional cycle of operation being followed consists of drilling of holes, charging of these holes with explosives and initiation accessories followed by blasting, loading of blasted rock of proper size into the transporting vehicle and despatch for further process of crushing. In the process of crushing, raw stone boulders are converted into stone aggregates of suitable sizes in various stages. Some construction applications like rip-rap, gabion walls, embankment of slopes etc. require the raw stone boulders from a quarry to be used in raw form without application of crushing function [7, 8]. Most of the stone crushing plant in India have a maximum intake size of (-) $500 \mathrm{~mm}$. Considering the compactness of rock mass and size of the boulders to be loaded, back-hoe hydraulic excavator is the most common loading equipment used in stone quarries. However, there are cases where Run-off-Mine (ROM) size is as low as (-) $250 \mathrm{~mm}$, especially where crushing plants located in vicinity have smaller capacity and intake size. In such cases, front end loader serves dual purpose - loading of raw stone 
boulders in the quarry and loading of crushed aggregates at the crushing plant.

Loading of blasted muck is key activity in any mining operation which accounts for a considerable portion of the overall mining cost. Brunton et al. demonstrated that significant savings in mining cost can be made by making the loading activity more efficient by means of optimising rock fragmentation and geometry of the blasted muck pile [9]. According to Choudhary the properties of the blasted muckpile is one of the key factors affecting performance of the loading equipment [10]. The pile of mineral or rock obtained after blasting is called muckpile. Throw, drop and lateral spread are the properties of the muckpile which significantly affect selection and productivity of loading equipment. Throw is defined as the distance of movement of the centre point of gravity of a rock mass from its origin in the bench to the centre of the muck pile formed after blasting [11]. Drop of muckpile is the vertically lowering of the blasted muck from its collar level and lateral spreading is the horizontal distance up which the blasted muck lies. Figure 1 illustrates each of these parameters.

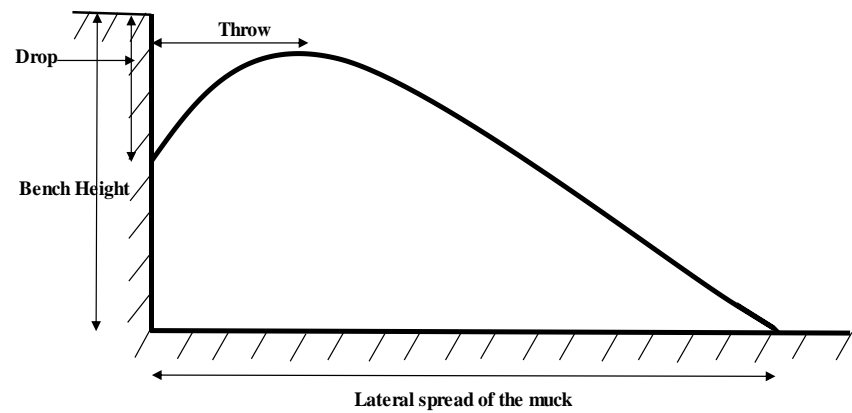

Figure 1. Muckpile profile parameters [10]

Throw, drop and lateral spread are essential parameters which govern looseness of the blasted muck and hence, effective loading operation. Tosun et al. stated that few most important parameters for loader efficiency are the loader approach angle to the pile, the filling and lifting time of the loaders, and the bucket fill factor [12]. Different profiles of blasted muckpile and concentration of voids in it determine digging time, bucket fill factor, and the diggability, which in turn, influence the loading cycle time and output from the excavator. According to Brunten et al., excavator dig time is defined as the period from when the bucket engages the muckpile to when it starts to swing or disengage. The bucket fill factor is defined as the ratio between the nominal volumetric capacity and the actual volume of material in the bucket. Diggability can be defined as the ease with which the shovel digs a rock unit. If the dig time is low, the muck pile is considered to have high diggability, if the digging time is big then the muckpile is considered to have low diggability [13, $14]$.

Improper throw and drop of blast muck results into tight muck piles lying close to the face which makes digging of the blasted muck cumbersome. Optimum throw and drop, generates desired blasted muckpile geometry which facilitate the digging of the muck [15]. Basis the spatial correlation of throw, drop and lateral spread, there could be three different muckpile profiles resultant from a blast which are shown in Figure 2.

Case 1 exhibits larger spread, low height of the muck pile which poses problems with back hoe hydraulic excavators as more time is spent on accumulation of material to attain desired bucket fill factor and hence, productivity with backhoe excavator in this case is low whereas front end loader should be more productive in this case. Case 2 exhibits muck pile with low spread and high height. This profile provides high bucket fill factor and forward movement of muck under gravity during loading and hence, productivity with back hoe excavator is high whereas this profile is difficult to handle with front end loader. However, in this case, due to tightness of the muck and less concentration of voids, the digging speed of the bucket becomes a challenge. Case 3 shows a case where both the spread and height of muck are moderate, muckpile is loose, concentration of voids is moderate and productivity with back hoe loaders is reasonably high [16].

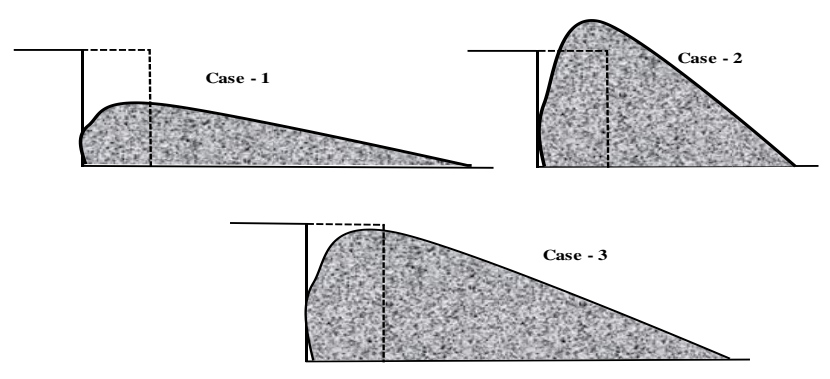

Figure 2. Muckpile profile parameters [16]

The above illustration show that muck profile has a considerable influence on both selection and performance of excavator. At the same time, throw, drop and lateral spreading of muck pile are important parameters which indicate the efficacy of blast design. Singh et. al. demonstrated that there are explainable relations among various blast design parameters i.e. burden, spacing, stemming, bench height, bench stiffness ratio, and powder factor and distances of throw and lateral spread [17]. Rai et al. also found such relation and efforted to augment the muck pile throw and drop to suit loading conditions [18].

While there have been a good deal of studies and research undertaken to ascertain influence of blast design parameters on blasted muckpile properties in metallic and other major minerals, such investigations in stone quarries or other minor minerals are limited. Stone quarries in India pose many operational and engineering challenges in form of small mining area, lower bench heights, difficult geological conditions, vicinity of residential and other structures, and deployment of excavators of smaller bucket sizes - dominantly $0.9 \mathrm{~m}^{3}$ to $1.2 \mathrm{~m}^{3}$ - due to requirement of segregation and small production volumes. This paper, supported by structured and rigorous field work, efforts to bring out influence imparted by blast design parameters on properties of muckpile in Indian stone quarries and find out the numerical values of key blast design parameters which result into the blasted muckpile profile to provide optimum operating performance of the excavator, as observed in the field as well as recommended by the excavators' original equipment manufacturers.

\section{FIELD DESCRIPTION}

Field experiments were conducted in three different quarries of building stones situated in Bakhrija village of Mahendragarh district in the Indian state of Haryana. These quarries are located adjacent to each other and are spread over 
dimensions of 1600 meters in NS direction and 1100 meters in EW direction with some non-mining / buffer area falling in between. These quarries are known as Bakhrija Mining Plot 1, 2 and 4 respectively and have sanctioned mining lease areas of 11.5 hectares, 21.65 hectares and 34.64 hectares respectively. Views of the quarries captured during the experiments are as per Figure 3.

The petrographic investigation shows that the rock mass contains 70-75 \% quarts, 20-25\% feldspar, 1-2 \% mica, 2-3\% iron oxide. Key geo-mechanical properties of the rock mass (black quartzite) are furnished in the Table 1.

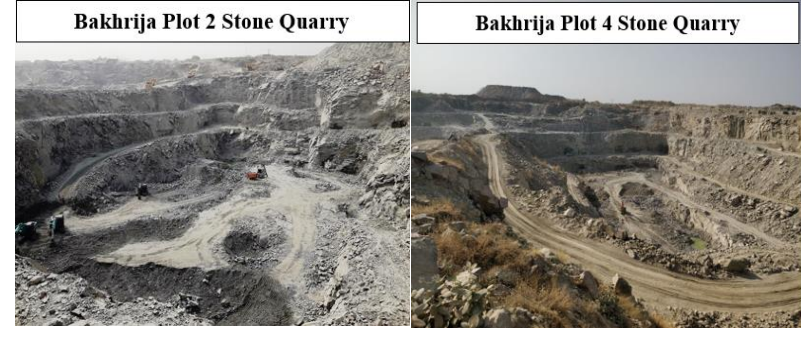

Figure 3. View of Bakhirja Plot $2 \& 4$ Masonry Stone Quarries

Table 1. Key geo-mechanical properties of rock mas in quarries under study

\begin{tabular}{cccc}
\hline S. N. & Physical / Mechanical Property & Observed Value & Test Protocol \\
\hline 1 & Specific Gravity & $2.79 \mathrm{gm} / \mathrm{cc}$ & IS:2386 (Part III)-1963-2011 \\
2 & Water Absorption & $0.2 \% \mathrm{w} / \mathrm{w}$ & IS:2386 (Part III)-1963-2011 \\
3 & Aggregates Impact Value & $16 \%$ & IS:2386 (Part IV)-1963-2011 \\
4 & Aggregates Crushing Value & $19 \%$ & IS:2386 (Part IV)-1963-2011 \\
5 & Los Angles Abrasion Value & $25 \%$ & IS:2386 (Part IV)-1963-2011 \\
6 & Stripping Value & $96 \%$ & IS:6241 - 2008 \\
7 & $10 \%$ Fines Value & 24 tons & IS:2386 (Part IV)-1963-2011 \\
\hline
\end{tabular}

Table 2. Engineering properties of explosives and accessories used during study

\begin{tabular}{cccc}
\hline S. No. & Property & \multicolumn{2}{c}{ Description } \\
& & Primer Charge & Column Charge \\
\hline 1 & Weight \& diameter of cartridge & $2.78 \mathrm{~kg}, 83 \mathrm{~mm}$ & $2.78 \mathrm{~kg}, 83 \mathrm{~mm}$ \\
2 & Nominal density & $1.20 \mathrm{~g} / \mathrm{cc}$ & $1.20 \mathrm{~g} / \mathrm{cc}$ \\
3 & Relative weight strength & $85-130 \%$ & $75-92 \%$ \\
4 & Relative bulk strength & $109-184 \%$ & $98-130 \%$ \\
5 & Velocity of detonation (VoD) & $3800 \mathrm{~m} / \mathrm{s}$ & $3500 \mathrm{~m} / \mathrm{s}$ \\
\hline
\end{tabular}

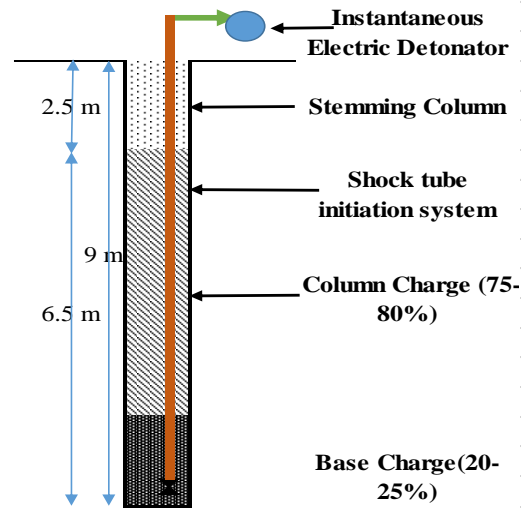

Figure 4. Cross section of a representative blast hole charging at Bakhrija stone quarries

A total of 40 blasts were included in the study spanned over a period of 12 months from January 2016 to December 2017. Variations were produced in four key blast design parameters namely bench height, burden, spacing and stemming which in turn affected other indirect parameters like spacing to burden ratio, bench stiffness ratio and powder factor. Due attention was paid to the fact while varying one factor, other three factors were kept constant. For first 10 blasts, bench height, spacing and stemming length were kept constant and burden was varied to observe the variation in muckpile geometry. For next 10 blasts, bench height, burden and stemming were pegged and spacing was changed systematically and muckpile properties were measured. In next 10 blasts, bench height, burden and spacing were pegged and variations were created in stemming length. In the last ten blasts, spacing and stemming were hinged, and bench height and burden were altered to get variability in bench stiffness ratio, and its impact on muckpile geometry was recorded. Type of drilling machine, drill angle, type and make of explosives and accessories, and initiation patterns / firing sequence were kept constant throughout the study period. Drilling was done with pneumatically driven machines with finished hole diameter of $110 \mathrm{~mm}$ with drill hole angle kept completely vertical. Holes were charged with class 2 cartridged slurry high explosives as primer charge $(20-25 \%)$ and class 2 cartridged slurry low explosives as columns charge (75-80 \%). Engineering properties of explosives as provided by the explosive's manufacturer used are as per Table 2.

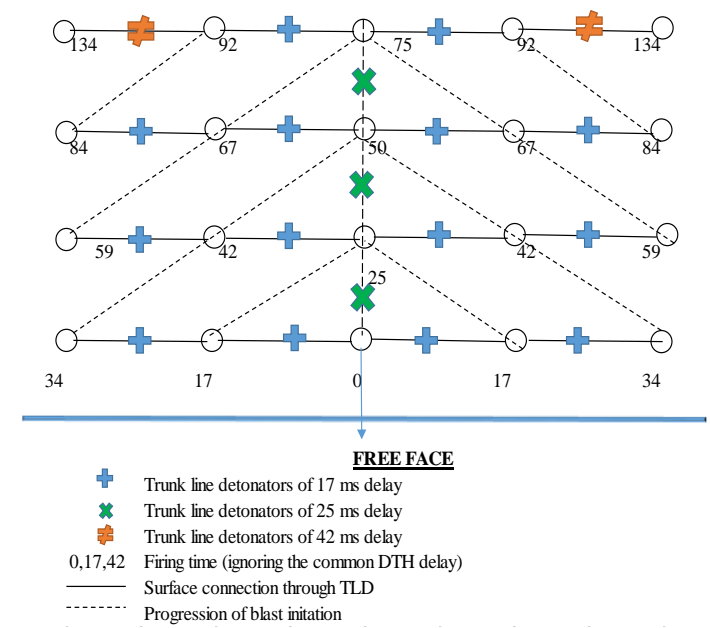

Figure 5. Layout of firing pattern followed at mines under study 
Initiation was through combination of instantaneous electric detonator and non-electric down the hole delay detonator of 450 milliseconds in-built delay. Surface connection was done using non-electric trunk line delay detonators of 17 milliseconds, 25 milliseconds and 42 milliseconds in-built delays. A scheme of charged blast hole of 9 meters length is as per the Figure 4.

Blast holes were arranged in square pattern and $\mathrm{V}$ or skewed $\mathrm{V}$ type of initiation sequence was followed throughout the study period. Figure 5 shows the arrangement of drill holes and firing sequence.

Post blasting, throw, drop and lateral spread were measured manually taking offsets and using a steel tape.

\section{FIELD EXPERIMENTS - ANALYSIS AND RESULT}

The data set including blast design inputs and post blast muckpile profile are as per the Table 3 .

Table 3. Details of blast design parameters and resultant data set

\begin{tabular}{|c|c|c|c|c|c|c|c|c|c|c|c|c|c|c|}
\hline $\begin{array}{l}\dot{z} \\
\dot{\boldsymbol{z}}\end{array}$ & $\begin{array}{l}\frac{0}{0} \\
\frac{0}{0} \\
\dot{0} \\
\dot{0}\end{array}$ & 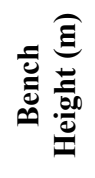 & 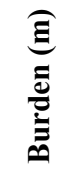 & 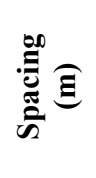 & 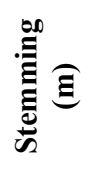 & 胥 & 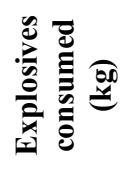 & 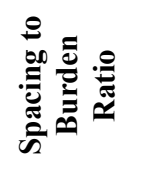 & 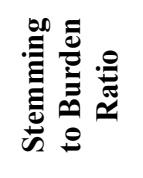 & 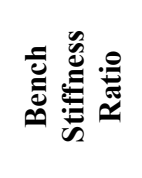 & $\underset{0}{\stackrel{0}{0}}$ & 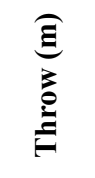 & 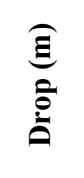 & 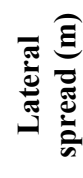 \\
\hline 1 & 75 & 9.00 & 2.00 & 3.00 & 2.75 & 4050.00 & 4900.00 & & & & 1.21 & 12.20 & 5.70 & 48.00 \\
\hline 2 & 41 & 9.00 & 2.20 & 3.00 & 2.75 & 2435.40 & 2675.00 & & & & 1.10 & 11.20 & 5.90 & 46.00 \\
\hline 3 & 40 & 9.00 & 2.25 & 3.00 & 2.75 & 2430.00 & 2525.00 & & & & 1.04 & 11.70 & 5.30 & 44.00 \\
\hline 4 & 56 & 9.00 & 2.30 & 3.00 & 2.75 & 3477.60 & 3550.00 & & & & 1.02 & 12.10 & 5.10 & 48.00 \\
\hline 5 & 43 & 9.00 & 2.40 & 3.00 & 2.75 & 2786.40 & 2700.00 & No & & & 0.97 & 11.90 & 5.00 & 38.00 \\
\hline 6 & 44 & 9.00 & 2.50 & 3.00 & 2.75 & 2970.00 & 2650.00 & Variation & & & 0.89 & 11.00 & 4.70 & 33.00 \\
\hline 7 & 39 & 9.00 & 2.60 & 3.00 & 2.75 & 2737.80 & 2450.00 & & & & 0.89 & 11.00 & 5.20 & 35.00 \\
\hline 8 & 27 & 9.00 & 2.70 & 3.00 & 2.75 & 1968.30 & 1850.00 & & & & 0.94 & 10.80 & 5.00 & 37.00 \\
\hline 9 & 50 & 9.00 & 2.80 & 3.00 & 2.75 & 3780.00 & 3250.00 & & & & 0.86 & 10.20 & 4.80 & 33.00 \\
\hline 10 & 68 & 9.00 & 2.90 & 3.00 & 2.75 & 5324.40 & 4450.00 & & No & & 0.84 & 9.00 & 3.00 & 30.00 \\
\hline 11 & 100 & 9.00 & 2.30 & 2.50 & 2.75 & 5175.00 & 6100.00 & 1.09 & Variation & & 1.18 & 10.00 & 5.00 & 42.00 \\
\hline 12 & 41 & 9.00 & 2.30 & 2.60 & 2.75 & 2206.62 & 2575.00 & 1.13 & & & 1.17 & 10.30 & 4.60 & 43.50 \\
\hline 13 & 107 & 9.00 & 2.30 & 2.70 & 2.75 & 5980.23 & 6700.00 & 1.17 & & & 1.12 & 11.00 & 5.70 & 44.00 \\
\hline 14 & 42 & 9.00 & 2.30 & 2.80 & 2.75 & 2434.32 & 2675.00 & 1.22 & & & 1.10 & 11.20 & 5.00 & 47.00 \\
\hline 15 & 99 & 9.00 & 2.30 & 2.90 & 2.75 & 5942.97 & 6450.00 & 1.26 & & No & 1.09 & 11.50 & 5.20 & 50.00 \\
\hline 16 & 43 & 9.00 & 2.30 & 3.00 & 2.75 & 2670.30 & 2700.00 & 1.30 & & Variation & 1.01 & 12.00 & 6.20 & 51.00 \\
\hline 17 & 82 & 9.00 & 2.30 & 3.10 & 2.75 & 5261.94 & 5350.00 & 1.35 & & & 1.02 & 11.70 & 4.20 & 48.00 \\
\hline 18 & 57 & 9.00 & 2.30 & 3.20 & 2.75 & 3775.68 & 3700.00 & 1.39 & & & 0.98 & 11.20 & 5.20 & 46.00 \\
\hline 19 & 43 & 9.00 & 2.30 & 3.25 & 2.75 & 2892.83 & 2800.00 & 1.41 & & & 0.97 & 11.00 & 4.90 & 41.00 \\
\hline 20 & 45 & 9.00 & 2.30 & 3.30 & 2.75 & 3073.95 & 2950.00 & 1.43 & & & 0.96 & 11.40 & 3.90 & 45.00 \\
\hline 21 & 33 & 9.00 & 2.30 & 3.00 & 2.10 & 2049.30 & 2100.00 & & 0.91 & & 1.02 & 12.60 & 7.20 & 64.00 \\
\hline 22 & 20 & 9.00 & 2.30 & 3.00 & 2.20 & 1242.00 & 1300.00 & & 0.96 & & 1.05 & 12.10 & 7.00 & 54.00 \\
\hline 23 & 23 & 9.00 & 2.30 & 3.00 & 2.30 & 1428.30 & 1475.00 & & 1.00 & & 1.03 & 11.80 & 6.20 & 49.00 \\
\hline 24 & 38 & 9.00 & 2.30 & 3.00 & 2.40 & 2359.80 & 2475.00 & & 1.04 & & 1.05 & 12.00 & 6.60 & 50.00 \\
\hline 25 & 78 & 9.00 & 2.30 & 3.00 & 2.50 & 4843.80 & 5325.00 & & 1.0 & & 1.10 & 10.50 & 5.20 & 47.00 \\
\hline 26 & 36 & 9.00 & 2.30 & 3.00 & 2.60 & 2235.60 & 2450.00 & & 1.1 & & 1.10 & 10.10 & 4.90 & 44.00 \\
\hline 27 & 45 & 9.00 & 2.30 & 3.00 & 2.70 & 2794.50 & 3075.00 & & 1. & & 1.10 & 9.00 & 5.00 & 39.00 \\
\hline 28 & 68 & 9.00 & 2.30 & 3.00 & 2.80 & 4222.80 & 4575.00 & & 1.22 & & 1.08 & 9.30 & 4.70 & 37.00 \\
\hline 29 & 45 & 9.00 & 2.30 & 3.00 & 2.90 & 2794.50 & 3200.00 & & 1.26 & & 1.15 & 9.20 & 5.90 & 37.00 \\
\hline 30 & 47 & 9.00 & 2.30 & 3.00 & 3.00 & 2918.70 & 3300.00 & No & 1.30 & & 1.13 & 7.10 & 3.80 & 31.00 \\
\hline 31 & 81 & 6.00 & 2.20 & 2.75 & 2.25 & 2940.30 & 2325.00 & Variation & & 2.73 & 0.79 & 5.90 & 2.70 & 28.00 \\
\hline 32 & 23 & 7.00 & 2.20 & 2.75 & 2.25 & 974.05 & 825.00 & & & 3.18 & 0.85 & 7.90 & 2.30 & 33.00 \\
\hline 33 & 28 & 8.00 & 2.20 & 2.75 & 2.25 & 1355.20 & 1225.00 & & & 3.64 & 0.90 & 8.50 & 2.50 & 37.00 \\
\hline 34 & 64 & 11.00 & 2.20 & 2.75 & 2.25 & 4259.20 & 4300.00 & & & 5.00 & 1.01 & 11.90 & 4.90 & 59.00 \\
\hline 35 & 82 & 11.00 & 2.50 & 2.75 & 2.25 & 6201.25 & 5475.00 & & No & 4.40 & 0.88 & 9.60 & 5.10 & 58.00 \\
\hline 36 & 30 & 6.00 & 2.00 & 2.75 & 2.25 & 990.00 & 850.00 & & Variation & 3.00 & 0.86 & 4.90 & 2.10 & 33.00 \\
\hline 37 & 66 & 11.00 & 2.60 & 2.75 & 2.25 & 5190.90 & 4425.00 & & & 4.23 & 0.85 & 11.30 & 5.10 & 49.00 \\
\hline 38 & 90 & 11.00 & 2.70 & 2.75 & 2.25 & 7350.75 & 6025.00 & & & 4.07 & 0.82 & 10.75 & 5.20 & 41.00 \\
\hline 39 & 44 & 7.00 & 2.30 & 2.75 & 2.25 & 1948.10 & 1600.00 & & & 3.04 & 0.82 & 8.20 & 3.10 & 31.00 \\
\hline 40 & 26 & 11.00 & 2.80 & 2.75 & 2.25 & 2202.20 & 1750.00 & & & 3.93 & 0.79 & 10.00 & 4.80 & 43.00 \\
\hline
\end{tabular}

Graphical analysis and its interpretation on finding relationship between various drill-blast design parameters and fragmentation are detailed below.

\subsection{Influence of burden on muckpile properties}

First 10 blasts were studied to ascertain influence of burden on muckpile properties. For a bench height of 9.0 meters, burden was moved from 2.0 meters to 2.9 meters while keeping spacing and stemming fixed at 3.0 meters and 2.75 meters respectively. Impact of burden on throw, drop and lateral spread is as per Figure $6,7 \& 8$.

It was observed that throw, drop and lateral spread of the muckpile decreased with increment in burden values. At low values of burden, the thickness of burden rock mass beam was low and the explosion energy found less resistance to effectively fracture and displace the rock. Also, at low values of burden, the ejection velocity of the muckpile was high 
which results in higher lateral and vertical displacement of rock mass. As burden was increased, the thickness of burden rock mass increased and explosives energy encountered enhanced resistance in displacing the rock volume. This reduced the ejection velocity of muckpile and quantum of displacement of rock along horizontal and vertical dimensions reduces. Desired muckpile profile to provide optimum performance of excavator was achieved at burden value of 2.25 to 2.30 metres which correspond to 20-21 times the blast hole diameter.

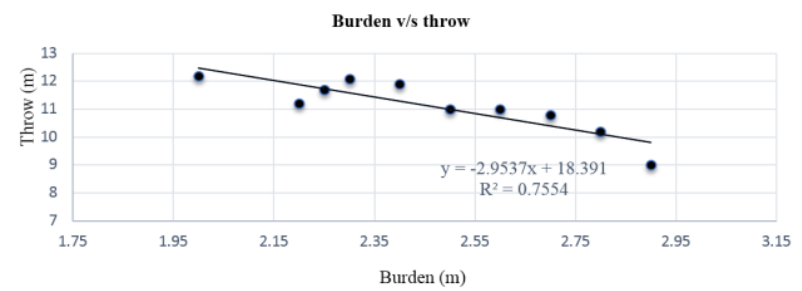

Figure 6. Relation between burden and throw of the muckpile

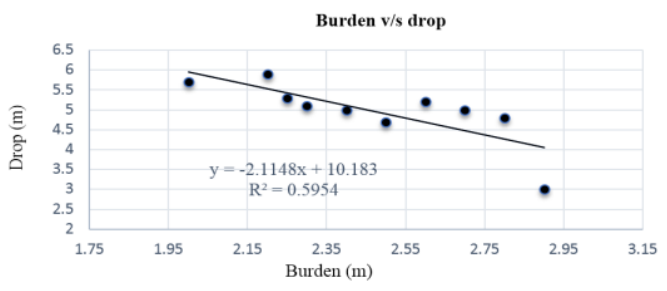

Figure 7. Relation between burden and drop of the muckpile

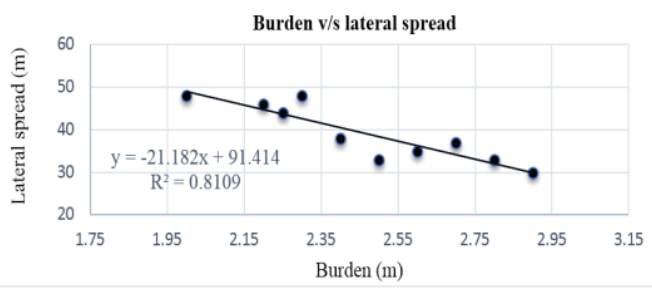

Figure 8. Relation between burden and lateral of the muckpile

\subsection{Influence of spacing to burden ratio on muckpile properties}

Next 10 blasts were aimed to evaluate influence of spacing to burden ratio on muckpile properties. For a bench height of 9.0 meters, spacing was moved from 2.5 meters to 3.3 meters while keeping burden and stemming fixed at 2.3 meters and 2.75 meters respectively. Impact of spacing to burden ratio on throw, drop and lateral spread is as per Figure 9, $10 \& 11$.

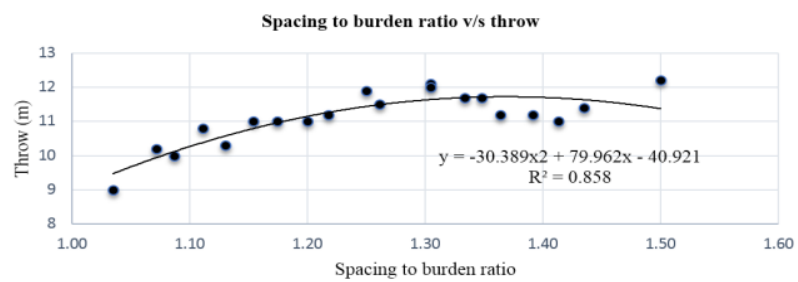

Figure 9. Relation between spacing to burden ratio and throw of the muckpile

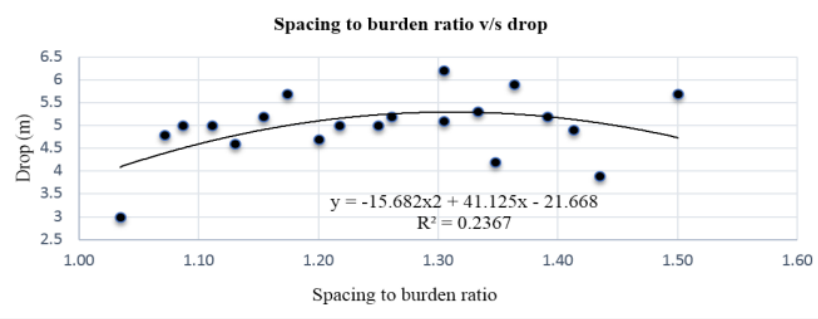

Figure 10. Relation between spacing to burden ratio and drop of the muckpile

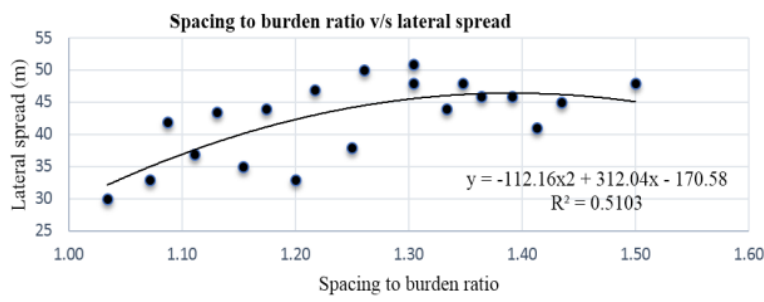

Figure 11. Relation between spacing to burden ratio and throw of the muckpile

Throw, drop and lateral spread of the blasted muckpile increased up to a spacing to burden ratio of 1.30 and started decreasing thereafter. Muckpile profile to suit the optimum loading conditions were recorded when spacing to burden value was in range of 1.30 to 1.40 . Very small values of spacing, against a fixed burden, caused inadequate and improper distribution and confinement of explosives energy which resulted in less horizontal and vertical movement of blasted material. As spacing was increased to a certain limit for a fixed burden distance, explosives energy was properly confined and used in creating radial fractures which resulted in higher throw, drop and lateral spread. Effective breakage and rock movement decreased with increase in spacing beyond certain level as the availability of explosion energy per unit of area under breakage decreased.

\subsection{Influence of stemming to burden ratio on muckpile properties}

Next 10 blasts were designed to evaluate impact of stemming to burden ratio on muckpile properties. For a bench height of 9.0 meters, stemming was moved from 2.1 meters to 3.0 meters while keeping burden and spacing fixed at 2.3 meters and 3.0 meters respectively. Impact of stemming to burden ratio on throw, drop and lateral spread is as per Figure. $12,13 \& 14$

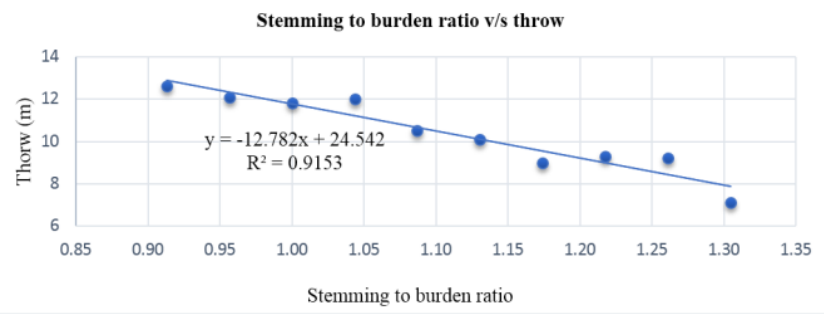

Figure 12. Relation between stemming to burden ratio and throw of the muckpile 


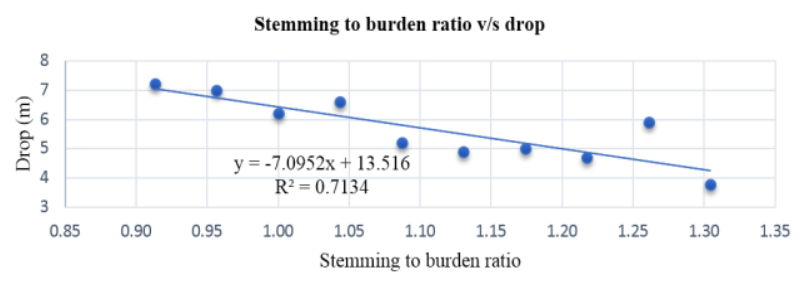

Figure 13. Relation between stemming to burden ratio and drop of the muckpile

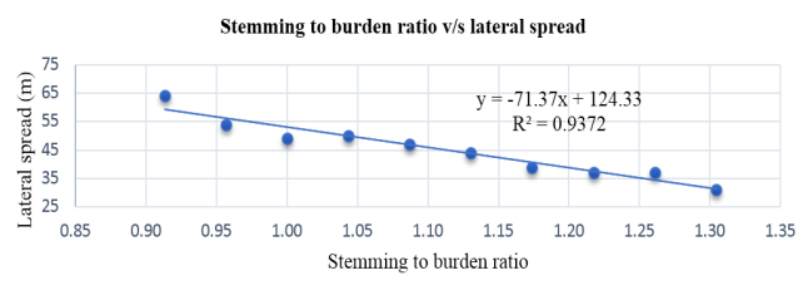

Figure 14. Relation between stemming to burden ratio and lateral spread of the muckpile

As shown, throw, drop and lateral spread decreased with increment in stemming over a fixed burden as both horizontal and vertical movement of muckpile was hampered progressively when length of stemming column was increased. Optimum operating conditions were obtained when stemming to burden ratio was between 0.90 to 1.05 . Stemming is the top most portion of the blast hole which is filled with nonexplosive and inert material which serves to confine and retain the explosion gases to effect proper breakage. However, when stemming was increased beyond a point after such confinement was achieved, it impacted the result of blast adversely in form of generation of large sized boulders from the collar region and restricted movement of muckpile because increased concentration of oversized boulders hampered the trajectory of muckpile.

\subsection{Influence of bench stiffness ratio on muckpile properties}

For the last 10 blasts, both spacing and stemming were pegged at 2.75 meters and 2.25 meters respectively and variations in bench height and burden were brought in order to alter the bench stiffness ratio. Bench height was varied from 6 meters to 11 meters; burden was kept fixed as long as variation in bench height was possible. When a bench height was repeated for study, burden was changed according to the site conditions. Influence of bench stiffness ratio on throw, drop and lateral spread is as shown in Figure 15, 16, and 17.

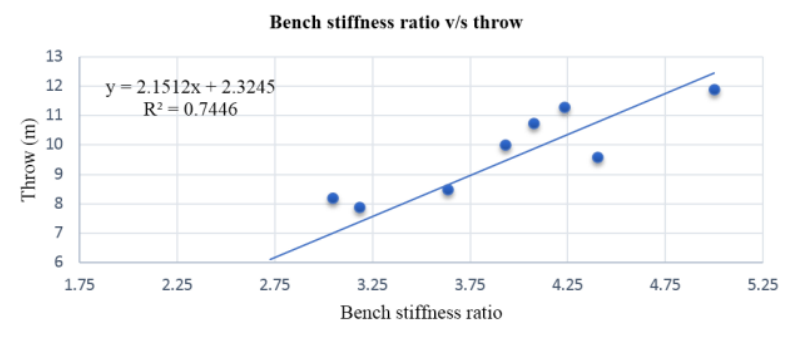

Figure 15. Relation between bench stiffness ratio and throw of the muckpile

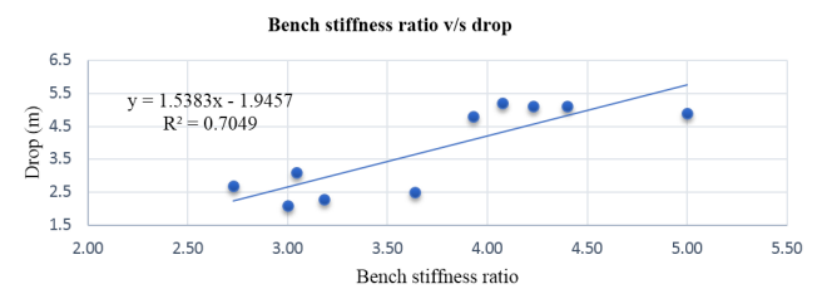

Figure 16. Relation between bench stiffness ratio and drop of the muckpile

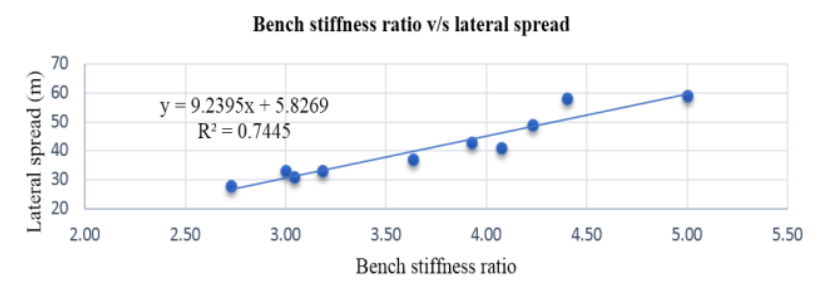

Figure 17. Relation between bench stiffness ratio and lateral spread of the muckpile

It was observed that throw, drop and lateral spread showed strong positive correlation with bench stiffness ratio. With increase in the bench stiffness ratio, the burden rock mass beam under flexion became more flexible and less stiff and made the rock mass easier to get deformed and displaced to higher dimensions. Muckpile profile which provided optimum operating performance of the excavator was achieved when bench stiffness ratio was in range of 4.0 to 4.25 .

\subsection{Influence of powder factor on muckpile properties}

Due to variations made in values of spacing, burden, stemming and bench height, powder factor and geological conditions, values of powder factor moved from $0.79 \mathrm{~kg} / \mathrm{cum}$ to $1.21 \mathrm{~kg} / \mathrm{cum}$. Relation between powder factor and muck properties are as shown in Figure 18, 19, and 20.

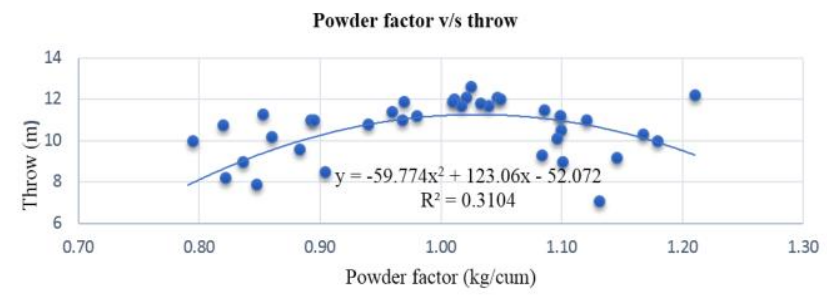

Figure 18. Relation between powder factor and throw of the muckpile

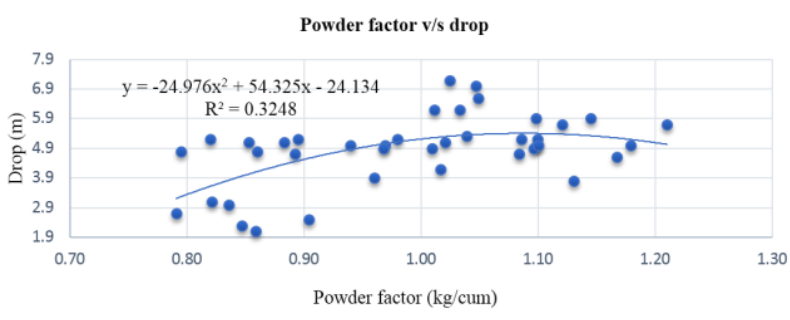

Figure 19. Relation between powder factor and drop of the muckpile 


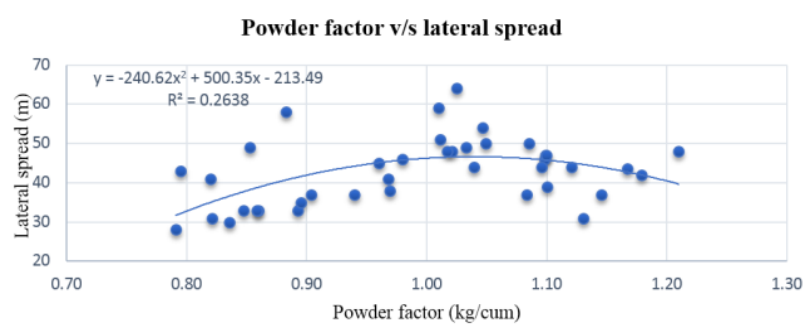

Figure 20. Relation between powder factor and lateral spread of the muckpile

All three muckpile properties i.e. throw, drop and lateral spread exhibited polynomial relation with powder factor. These values increased from powder factor of $0.79 \mathrm{~kg} / \mathrm{cum}$ to $1.05 \mathrm{~kg} /$ cum approximately and started falling thereafter. This can be explained as that the actual requirement of explosives energy to create breakage and cause displacement of rock mass kept increasing till a powder factor of $1.05 \mathrm{~kg} / \mathrm{cum}$ was achieved. However, increasing availability of explosives energy didn't mean increased utilization of it. Increasing powder factor beyond a certain limit caused untoward post blast effects like early ejection of stemming column, overbreaks, air blasts etc. which left less explosion energy to cause actual fracturing and movement of rock mass. Hence, throw, drop and lateral spread showed decreasing trend after powder factor value of $1.05 \mathrm{~kg} / \mathrm{cum}$ approximately. Optimum operating conditions for excavator were obtained at powder factor values in range of $0.95 \mathrm{~kg} / \mathrm{cum}$ to $1.05 \mathrm{~kg} / \mathrm{cum}$.

\subsection{Variation in inputs and its impact on output}

The range of variation made in blast design parameters and the trend and quantification of their impact on blasted muckpile geometry is as per the table 4 .

Table 4. Summary of changes in input parameters and trend, and variation in muckpile geometry

\begin{tabular}{|c|c|c|c|c|c|c|c|c|}
\hline $\begin{array}{c}\text { S. } \\
\text { No. }\end{array}$ & $\begin{array}{c}\text { Parameters } \\
\text { varied }\end{array}$ & $\begin{array}{c}\text { Base } \\
\text { value }\end{array}$ & $\begin{array}{c}\text { Maximum } \\
\text { variation } \\
\text { value }\end{array}$ & $\begin{array}{l}\text { Range of } \\
\text { variation } \\
(\%) \\
\end{array}$ & Trend of relation & $\begin{array}{l}\text { Change in } \\
\text { throw (\%) }\end{array}$ & $\begin{array}{l}\text { Change in } \\
\text { drop (\%) }\end{array}$ & $\begin{array}{c}\text { Change in } \\
\text { lateral } \\
\text { spread (\%) }\end{array}$ \\
\hline 1 & Burden (m) & 2.30 & 3.0 & $45 \%$ & Inversely proportional & $26 \%$ & $49 \%$ & $38 \%$ \\
\hline 2 & $\begin{array}{l}\text { Spacing to } \\
\text { burden ratio }\end{array}$ & 1.09 & 1.43 & $32 \%$ & $\begin{array}{l}\text { Downward exponential, } \\
\text { increment till Spacing to } \\
\text { burden ratio of } 1.3 \text {, } \\
\text { decrease thereafter }\end{array}$ & $20 \%$ & $59 \%$ & $24 \%$ \\
\hline 3 & $\begin{array}{l}\text { Stemming to } \\
\text { burden ratio }\end{array}$ & 0.91 & 1.30 & $43 \%$ & Inversely proportional & $44 \%$ & $47 \%$ & $52 \%$ \\
\hline 4 & $\begin{array}{c}\text { Bench } \\
\text { stiffness ratio }\end{array}$ & 2.73 & 5.00 & $83 \%$ & Directly proportional & $143 \%$ & $148 \%$ & $111 \%$ \\
\hline 5 & $\begin{array}{l}\text { Powder factor } \\
(\mathrm{kg} / \text { cum })\end{array}$ & 1.21 & 0.79 & $53 \%$ & $\begin{array}{c}\text { Downward exponential, } \\
\text { increment till powder factor } \\
\text { of } 1.05 \mathrm{~kg} / \mathrm{cum} \text {, decrease } \\
\text { thereafter }\end{array}$ & $157 \%$ & $243 \%$ & $129 \%$ \\
\hline
\end{tabular}

\section{CONCLUSION}

Key blast design parameters i.e. burden, spacing, stemming, bench stiffness ratio and powder factor were moved systematically and analysed to measure their influence on muckpile properties, namely, throw, drop and lateral spread, in order to ascertain the most optimum set of blast design parameters to achieve muckpile properties for optimum operating performance of the loading equipment.

Relation between burden and the throw, drop and lateral spread of the blasted muckpile was found inversely proportional. The desired muckpile geometry which provided optimum performance of excavator was observed at burden value of 2.25 to 2.30 metres for a bench height of 9.0 metres. These values of burden correspond to approximately 20-21 times the blast hole diameter.

Throw, drop and lateral spread of muckpile were found to be related in downward exponential manner with spacing to burden ratio. For a bench height of 9.0 metres and burden of 2.3 metres, spacing to burden ratio from 1.30 to 1.40 was found to provide the desired muckpile profile.

Stemming influenced the throw, drop and lateral spread of the blasted muckpile in inversely proportionate manner. For a bench height of 9.0 metres and burden of 2.3 metres, stemming to burden ratio between 0.9 to 1.05 has been found to give the blasted muckpile profile for optimum operating performance of the excavator,
Muckpile throw, drop and lateral spread exhibited directly proportionate relation the bench stiffness ratio. Most productive blasted muckpile profile was obtained when bench stiffness ratio was between 4.0 and 4.25 .

Relation between powder factor and blasted muckpile properties was found to be downward exponential. Required muckpile conditions were achieved when powder factor was recorded between $0.95 \mathrm{~kg} / \mathrm{cum}$ to $1.05 \mathrm{~kg} / \mathrm{cum}$.

The above conclusions shall be useful for practicing mining engineers for stone quarries in similar rock mass condition in designing the blast to obtain the optimum muckpile profile for efficient operation of excavators.

\section{ACKNOWLEDGEMENT}

The authors express their sincere gratitude towards the management of M/s Madaan Associates, New Delhi, M/s Tirupati Viniyoge Private Limited, Kolkata and Gradient Business Consulting Private Limited, Kolkata where the studies were conducted, for their permission, help, support and co-operation. Authors would also like to acknowledge the support and co-operations extended by the mining team and front-line supervisors of these the companies. 


\section{REFERENCES}

[1] Pravakar P, Kumar DR. (2009). Infrastructure development and economic growth in India'. Journal of the Asia Pacific Economy 14(4): 351-365. http://dx.doi.org/10.1080/13547860903169340

[2] Pradeep A. (2015). Infrastructure in India: Challenges and the way ahead, Institute of Economic Growth. University of Delhi Working paper series no. E/350/2015.

[3] Anantha Murthy BS, Abhishek S. (2011). Mining for sustainable growth of Indian construction industry. Proceedings of Golden Jubilee Seminar on Mining Technology for Sustainable Development-MineTech'11, pp. 29-39.

[4] Abhishek S, Mishra AK, Choudhary BS. (2018). Sustainable exploitation of building stone in India emerging issues. Current Science 15(05): 838-844. http://dx.doi.org/10.18520/cs/v115/i5/838-84.

[5] Bureau of Indian Standards (1971). Specifications for coarse and fine aggregates from natural sources for concrete. Indian Standards (IS): 383-1970.

[6] Indian Road Congress on behalf of Government of India (2013). Ministry of roads. Transport and Highways (MORTH) Specification for Road and Bridge Works $5^{\text {th }}$ Revision.

[7] Froehlich D. (2013). Protecting bridge piers with loose rock riprap. Journal of Applied Water Engineering and Research 1(1): 39-57. https://doi.org/10.1080/23249676.2013.828486

[8] Toprak B, Sevim O, Kalkan I. (2016). Gabion walls and their use. International Journal of Advances in Mechanical and Civil Engineering 3(4): 56-58.

[9] Brunton I, Thornton D, Hodson R, Sprott D. (2003). Impact of blast fragmentation on hydraulic excavator dig time. Proceedings of the Fifth Large Open Pit Mining Conference, Kalgoorlie WA, pp. 39-48.

[10] Choudhary BS. (2016). Excavator selection based on muckpile shape parameters in low height benches. Journal of Mines, Metals \& Fuels 2016, 19-22.

[11] Rustan A. (1998). Rock blasting terms and symbols. A.A.Balkema, Rotterdam, Brookfield 58. https://doi.org/10.1201/9781466571785

[12] Tosun A, Konak G, Karakus D, Onur AH, Toprak T. (2012). Investigation of relationship between blasting pile density and loader productivity. Proceedings of $10^{\text {th }}$ International Symposium on Rock Fragmentation by Blasting, Fragblast 10, New Delhi, pp. 385-389. https://doi.org/10.1201/b13759-48

[13] Doktan M. (2001). Impact of blast fragmentation on truck shovel fleet performance. Proceedings of the $17^{\text {th }}$ International Mining Congress and Exhibition of Turkey, pp. 375-379.

[14] Kirmanli C, Ercelebi SG. (2009). An Expert system for hydraulic excavator and truck selection in surface mining. The Journal of the South African Institute of Mining and Metallurgy 109: 727-738.

[15] Piyush R, Yang, HS. (2010). Investigation of some blast design and evaluation parameters for fragmentation in limestone quarries. Journal of Korean Society for Rock Mechanics, Tunnel \& Underground Space 20(03): 183193.

[16] Chaudhary BS. (2013). Firing patterns and its effect in muckpile shape parameters and fragmentation in quarry blasts. International Journal of Research in Engineering

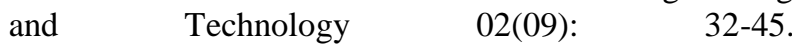
http://dx.doi.org/10.15623/ijret.2013.0209005

[17] Singh SP, Doorselaere DV. (2015). The relationship between blasting parameters and muck pile configuration. Proceedings of the $11^{\text {th }}$ International Symposium on Rock Fragmentation by Blasting, Sydney, NSW 369-374.

[18] Piyush R, Yang HS. (2010). Blast design for controlled augmentation of muck pile throw and drop. Journal of Korean Society for Rock Mechanics, Tunnel \& Underground Space 20(05): 360-368. 